Naskah diserahkan:13-09-2021; Direvis: i25-09-2021; Diterima: 27-09-2021

\section{Analisis Pemberdayaan Pendidikan di Kota Kendari dengan Metode One Help One}

Andi Syaiful Zainal ${ }^{1}$, Anwar Said ${ }^{2 *}$, Maulina ${ }^{3}$

Ilmu Pemerintahan, Universitas Muhammadiah Kendari ${ }^{1}$

Teknologi Hasil Perikanan, Universitas Muhammadiah Kendari ${ }^{2}$

Pendidikan Bahasa Inggris, Universitas Muhammadiah Kendari ${ }^{3}$

Email Korespondensi: anwar.said@umkendari.ac.id

\begin{abstract}
ABSTRAK: Masalah dalam penelitian ini adalah masih ditemukannya anak usia sekolah yang sulit melanjutkan pendidikannya disebabkan faktor kemiskinan keluarganya. Penelitian ini bertujuan untuk mengetahui dan menganalisis pemberdayan pendidikan masyarakat miskin di Kota Kendari. Penelitian ini menggunakan pendekatan kualitatif. Teknik pengumpulan data melalui observasi, wawancara mendalam dan studi dokumen.Data penelitian ini dianalisis secara deskriptif kualitatif. Temuan hasil penelitian menghasilkan pola pemberdayaan masyarakat yang berbeda dengan pemberdayaan pendidikan yang telah ada sebelumnya. Pada pemberdayaan pendidikan sebelumnya pihak pemerintah atau lembaga-lembaga swasta lebih dominan melakukan pemberdayaan pendidikan, sedangkan pada pola pemberdayaan pendidikan dengan pola one help one tersebut, pemberdayaan pendidikan sepenuhnya dilakukan oleh masyarakat secara mandiri, sedangkan pemerintah hanya memfasilitasi pemberdayaan pendidikan antara keluarga mampu dengan keluarga kurang mampu (miskin). Hasil pemberdayaan dengan pola one help one tersebut telah memberdayakan pendidikan sebanyak 283 kepala keluarga. Adapun wujud pemberdayaanya pendidikan adalah keluarga mampu memberikan beasiswa pendidikan sampai tingkat pendidikan dasar bagi satu keluarga kurang mampu.
\end{abstract}

Katakunci: one help one; pemberdayaan; pendidikan.

ABSTRACT: This study was the discovery of school-age children who had difficulty continuing their education because of the poverty of their families. It was to identify and analyze the education of the poor in the city of kendari. The study involves a qualitative approach. Data collection techniques were through observation, in-depth interviews, and document studies. Research findings reveal in a different pattern of people empowermentfrom existing education empowerment. With empowerment of previous education, governments and private institutions are more dominatively empowering education. Whereas on the pattern of education empowerment with the pattern one help one, education empowerment is entirely done by communities on their own, while governments only facilitate the empowerment of education between capable families and families of modest means. The results of empowerment with the pattern one help one have empowered a total of 283 family heads. As for the gifts of education, the family can afford an education scholarship up to the level of elementary education for one less family.

Katakunci: empowerment; education; one help one. 


\section{PENDAHULUAN}

Penduduk miskin merupakan warga masyarakat yang pada umumnya hanya memiliki pengeluaran perbulannya di bawah garis kemiskinan. Adapun garis kemiskinan dapat diukur dari batas minimum pengeluaran warga perkapita dalam satu bulan guna mencukupi kebutuhannya sehingga dapat dikategorikan miskin atau tidak (Nurwati, 2008). Tingkat kemiskinan di Sulawesi Tenggara pada umumnya masih tinggi, apabila dilihat dari jumlah total penduduknya, walaupun data menunjukkan terjadi penurunan dari tahun ke tahun. Ini terlihat dari pada bulan September 2016 jumlah penduduk miskin Sulawesi Tenggara mencapai 327,29 ribu jiwa dengan persentase sebesar 12,77 persen. Pada tahun berikutnya mengalami peningkatan hingga mencapai 331,71 ribu jiwa atau 12,81 persen. Namun pada tahun 2017 hingga tahun 2019 terjadi penurunan jumlah dan persentase penduduk miskin. Penurunan angka kemiskinan tersebut disebabkan oleh beberapa factor salah satu diantaranya yaitu kemampuan masyarakat memenuhi kebutuhan dasarnya (BPS, 2020).

Di Kota Kendari, jumlah penduduk miskin dari tahun ke tahun telah mengalami penurunan. Pada tahun 2008 jumlah penduduk miskin 23.600 jiwa dan pada tahun 2015 jumlah penduduk miskin turun menjadi 19.250 jiwa, sejak tahun 2008 penduduk miskin Kota Kendari sebesar 8,53\% dan terus mengalami penurunanhingga akhir tahun 2014. Pada tahun 2015 persentase jumlah penduduk miskin mengalami kenaikan sebesar 0,03\% walaupun kenaikannya sangat kecil. Menurunnya jumlah penduduk miskin di Kota Kendari banyak dipengaruhi oleh berbagai kebijakan pemerintah, namun melihat data di atas masih banyak pekerjaan rumah pemerintah Kota Kendari, karena pemerintah selalu dituntut untuk senantiasa memberdayakan warganya agar angka kemiskinan tersebut semakin menurun (Raintung dkk, 2021), karena apabila penduduk miskin masih cukup banyak maka akan berdampak pula pada rendahnya angka partisipasi pendidikan di Kota Kendari.

Berbagai upaya prioritas penanggulangan kemiskinan di Kota Kendari, khususnya dibidang pendidikan adalah memberikan prioritas peningkatankualitas pelayanan dan manajemen pendidikan dasar dan menengah serta pelestarian nilai-nilai budaya.Sasaran pada prioritas ini adalah meningkatnya angka partisipasi sekolah SD dan SLTP, meningkatnya mutu pendidikan serta terwujudnya organisasi sekolah sebagai unit pelayanan terdepan pendidikan yang professional, partisipatif, transparan, efisien dan akuntabel.

Pemerintah kota Kendari secara empiris telah melaksanakan berbagai program/kegiatan pemberdayaan khususnya disektor pendidikan, yang dalam hal ini dilaksanakan oleh SKPD atau Dinas Pendidikan Nasional sesuai dengan tugas pokok dan fungsinya. Aktifitas program/kegiatan yang dilakukan oleh SKPD Pemerintah Kota Kendari, diantaranya adalah penyediaan beasiswa bagi siswa dari keluarga yang tidak mampu(Rahman, 2016); (Puput et all, 2020).

Namun berbagai program pemberdayaan khususnya dibidang pendidikan tersebut belum menjangkau seluruh lapisan masyarakat, masih banyak didapati anak usia sekolah yang tidak mampu melanjutkan pendidikannya dan beralih di 
sektor informal seperti tukang pikul di pasar dan di pelabuhan, juru parkir, pedagang asongan di traffic light dan jasa pencucian kendaraan, pengamen, peminta sumbangan, pemulung dan pengemis (Elwan and Aslim 2019); (Eka N, 2020).

Mencermati fenomena tersebut, maka permasalahan pendidikan harus dipikirkan bersama dengan caramelibatkan semua unsur masyarakat, karena pendidikan bukan hanya menjadi tanggung jawab pemerintah saja, tetapi juga tanggung jawab seluruh eleman yang ada termasuk orang tua dan masyarakat, karena pendidikan dari, oleh dan untuk masyarakat (Kadir, 2013).

Berbagai kebijakan pemerintah untuk meningkatkan angka partisipasi pendidikan masyarakat telah dilaksanakan, salah satunya adalah Program Wajib Belajar 9 tahun dengan cara pemberian beasiswa kepada siswa yang berprestasi dan juga beasiswa kepada masyarakat miskin. Namun kebijakan tersebut semuanya berasal dan dilaksanakan sepenuhnya oleh pemerintah. Pada tahun 2017 pemerintah Kota Kendari melakukan terobosan dengan mengeluarkan suatu kebijakan unggulan yaitu Peraturan Walikota Kendari nomor 17 tahun 2008 tentang Persaudaraan Madani. Poin pokok dari Persaudaraan Madani ini adalah One Help One yaitu pemberdayaan masyarakat yang dilakukan sepenuhnya oleh masyarakat untuk masyarakat dengan pola One Help One atau satu keluarga mampu memberdayakan satu keluarga kurang mampu.

Adapun tujuan dari penelitian ini adalah untuk mendeskripsikan dan menganalisa pemberdayaan pendidikan masyarakat miskin dengan pola one help one.

\section{Pemberdayaan Masyarakat}

Pemberdayaan berasal dari bahasa Inggris "empowerment" yang secara harfiahnya yaitu "pemberkuasaan", atau juga pemberdayaan diartikan sebagai memberikan atau meningkatkan kekuasaan (power) keberdayaan kepada masyarakat lemah (Awang Azam, 2010: 45). Sedangkan menurut Usman (2004) kata pemberdayaan dapat diartikan sebagai suatu kegiatan untuk mengusahakan sesuatu dari keadaan sebelumnya yang tidak memiliki daya, tenaga, kekuatan menjadi keadaan atau situasi yang berdaya, bertenaga dan mempunyai kekuatan. Jadi dapat dikatakan pemberdayaan itu sebagai suatu proses dan tujuan (Yulianti, 2018).

Selanjutnya pemaknaan pemberdayaan masyarakat menurut Madekhan Ali (2007: 86) yang mendefinisikan pemberdayaan masyarakat sebagai bentuk keikutsertaan seseorang untuk melepaskan diri dari ketergantungan mental maupun fisik. Keterlibatan masyarakat tersebut merupakan faktor yang sangat penting dalam melakukan pemberdayaan, dengan alasan; pertama, keterlibatan masyarakat merupakan salah satu cara yang ampuh untuk menggerakkan sumber daya yang ada dan kedua adalah keterlibatan masyarakat dapat dijadikan alat untuk mengidentifikasi sejak awal segala yang menjadi persoalan masyarakat.

Pemberdayaan menurut Mc Ardle (Dalam Hikmat, 2010: 3) mengartikan pemberdayaan sebagai proses pengambilan keputusan oleh orang orang yang 
secara konsekuen melaksanakan keputusan tersebut. Selanjutnya pemberdayaan masyarakat dapat diartikan sebagai usaha yang dilakukan untuk mengembalikan atau memperluas keberdayaan suatu organisasi agar dapat berbuat sebagaimana apa yang diinginkan mereka dalam memperoleh hak-hak dan tanggung jawab mereka sebagai anggota organisasi atau sebagai seorang warga negara (Harahap, 2012).

Berdasarkan uraian tersebut di atas, pemberdayaan masyarakat dapat didefinisikan sebagai proses tindakan sosial dimana masyarakat memperoleh kekuasaan untuk bertindak secara efektif mengubah kehidupan dan lingkungannya (Margayaningsih, 2018). Proses tindakan sosial dalam pemberdayaan masyarakat mencakup keperdulian individual terhadap isu-isu tertentu, pengembangan kelompok-kelompok kebersamaan yang kecil, organisasi-organisasi komunitas, kemitraan, dan tindakan-tindakan sosial dan politik untuk menciptakan redistribusi sumber daya dan kekuasaan. Tema sentral dalam pemberdayaan masyarakat adalah kapasitas masyarakat untuk melakukan kontrol atas institusi-institusi yang mempengaruhi kehidupannya, dan perbaikan dalam kualitas hidup masyarakat.

Adapun tujuan dari pemberdayaan menurut Payne (Rifa'l: 2013) untuk mengupayakan masyarakat mendapatkan daya atau kekuatan agar mampu menentukan suatu keputusan dan mampu pula menentukan apa yang harus mereka laksanakan yang berhubungan dengan mereka sendiri, dengan tidak mengabaikan akibat dari hambatan pribadi dan sosial ketika mengambil keputusan tersebut. Dalam hal ini pemberdayaan tidak akan terjadi apabila tidak ada partisipasi dari masyarakat itu sediri (Agustina, dkk: 2018).

Tujuan pemberdayaan menuju kepada waktu saat hasil atau yang ingin dicapai kehadapan perubahan masyarakat yang berdaya guna dan mempunyai kesanggupandalam merubah dan memperbaiki keadaan sosial ekonomi warganya (Endah: 2020). Pendapat yang sama juga disampaikan oleh Sumodiningrat (2000), bahwa tujuan dari pemberdayaan masyarakat adalah berusaha meningkatkan dan mengembangkan taraf hidup dan kapasitas masyarakat yang berada dibawah garis kemiskinan dengan cara meningkatkan pendapatannya

\section{METODE PENELITIAN}

Penelitian ini dilaksanakan di Kota Kendari pada keluarga mampu dan keluarga kurang mampu yang telah menandatangani akta persaudaraan. Penentuan informan penelitian ini menggunakan metode Purposive (metode penunjukan secara sengaja) dengan alasan informan yang ditunjuk mengetahui dan memiliki kemampuan dan kewenangan untuk memberikan informasi yang dibutuhkan (sugiyono, 2012). Penetapan informan bertujuan untuk menggali informasi sebanyak mungkin dari objek yang dituju.

Pada penelitian ini telah ditentukan beberapa informan penelitian dari unsur pemerintah/birokrasi yaitu Walikota Kendari, Wakil Walikota Kendari, Kepala Bappeda Kota Kendari, Kepala Badan Pemberdayaan Masyarakat Kota Kendari, beberapa orang Camat Lurah se Kota Kendari. Sedangkan dari kelompok 
sasaran yaitu beberapa orang masyarakat yang mewakili masyarakat mampu dan masyarakat kurang mampu. Selain itu juga peneliti mengambil informan dari unsur akademisi.

Data dalam penelitian ini, bersumber dari data primer dan data sekunder. Data primer diperoleh dari wawancara dengan para informan terpilih, sedangkan data sekunder bersumber dari beberapa instansi terkait seperti Badan Pemberdayaan Masyarakat Kota Kendari, Bappeda Kota Kendari, Dinas Pendidikan dan Kebudayaan, Kantor Camat dan Lurah, Badan Pusat Statistik dan juga beberapa penelitian terdahulu yang relevan dengan penelitian. Selanjutnya penelitian ini dianalisa dengan menggunakan analisis data kualitatif Miles dan Huberman (1992). Analisis ini ditempuh melalui reduksi data, sajian data hingga penarikan kesimpulan.

\section{HASIL PENELITIAN DAN PEMBAHASAN}

\section{Hasil Penelitian}

Program One Help One yang dicetuskan oleh Walikota Kendari selanjutnya dibuatkan payung hukumnya, yaitu Peraturan Walikota Kendari Nomor 17 Tahun 2008 Tentang One Help One (Persaudaraan Madani). Dalam Peraturan Walikota tersebut memuat landasan filosofinya/tujuan luhurnya yaitu bahwa dalam rangka upaya mengentaskan kemisikinan dan membangun sosial antar sesama masyarakat kota, maka diperlukan sebuah pola pemberdayaan masyarakat, termasuk pemberdayaan pendidikan yang saling asah, asih dan asuh antar sesama warga kota. Adapun landasan Sosiologisnya atau fakta sosialnya yaitu bahwa pola pemberdayaan tersebut didasarkan pada konsep tata kehidupan sosial yang paripurna, yang bersumber dari penjabaran nilai-nilai agama, yang secara sosiologi bahwa manusia senantiasa hidup berkelompok dan saling membutuhkan antara satu dengan lainnya, sehingga tercipta tata kehidupan sosial yang harmonis, yang kita lembagakan dalam program one help one tersebut.

Secara operasional pola One Help One ini dijelaskan oleh Kepala Badan Perencanaan Pembangunan Daerah (Bappeda) Kota Kendaribertujuan untuk meningkatkan partisipasi masyarakat dalam bidang pendidikan. Diharapkan terjadi hubungan sosial yang harmonis antara sesama warga dan mengikis sikap hidup individual yang merasuk kebanyakan warga Kota Kendari, dengan menggugah kepedulian warga mampu untuk membantu pendidikan saudaranyayang kurang mampu, baik secara langsung maupun tidak langsung, misalnya dengan memberi beasiswa pendidikan bagi anak dari keluarga kurang mampu, atau memfasilitasi mendapatkan bantuan pendidikan dari pihak manapun juga.

Program ini sebenarnya merupakan sebuah kebijakan yang konstruktif demi meningkatkan pendidikan di Kota Kendari.Pola One Help One pertama 
memberdayakan pendidikan anak dari keluarga miskin oleh si kaya, atau si miskin oleh si mampu. Kedua, memberi pendidikan kepada si miskin (keluarga kurang mampu). Ketiga, memberi arahan untuk mendapatkan pendidikan yang layak demi kesejahteraan keluarga.

Pembentukan peserta pemberdayaan pendidikan dapat dilakukan melalui suatu prosedur yang telah ditetapkan dalam Peraturan Walikota Kendari nomor 17 tahun 2008. Adapun prosedur tersebut adalah sebagai berikut: (1) pengambilan data profil kedua belah pihak; (2) melakukan sosialisasi kepada para calon keluarga yang akan mengikuti program pemberdayaan pendidikan; (3) dilakukan fasilitasi pertemuan oleh tim mediasi pemerintah daerah; (4) penandatanganan akta persaudaraan yang dilakukan dihadapan Walikota Kendari yang disaksikan Wakil Walikota dan Sekretaris Kota Kendari.

\section{Pengambilan Data Profil Kedua Belah Pihak}

Secara umum, prosedur mempersaudarakan (memasangkan) saudara mampu dan saudara kurang mampu meliputi pengambilan data profi keluarga kedua belah pihak yang formatnya telah ditentukan pemerintah Kota Kendari, profil ini dibutuhkan untuk mengetahui siapa saja yang berhak dipersaudarakan. Berikut profil keluarga mampu sebagai berikut: (a) Nama (b) Alamat (c) Pekerjaan (d) Agama (e) Nomor KTP dan Kartu Keluarga (f) Nomor Telepon. Sedangkan profil keluarga kurang mampu sebagai berikut: (a) Nama (b) Status (c) Umur (d) Pekerjaan (e) Agama (f) Suku (g) Alamat (h) pendidikan terakhir (i) keadaan rumah saat ini, yang terdiri dari lantai, dinding, atap, kamar mandi, lampu, status tanah, lama tinggal, bahan bakar masak dan penghasilan perbulan.

\section{Melakukan Sosialisasi kepada para Calon Keluarga yang akan Dipersaudarakan}

Agar program pemberdayaan pendidikan ini memperoleh hasil yang optimal, maka masyarakat yang menjadi kelompok sasaran perlu memperoleh informasi yang memadai tentang program pemberdayaan pendidikan tersebut. Informasi tentang program tersebut perlu disampaikan kepada kelompok sasaran ini akan sangat menentukan apakah kelompok sasaran memberikan dukungan atau justru menolak kebijakan atau program yang akan diimplementasikan.

\section{Dilakukan Fasilitasi Pertemuan oleh Tim Mediasi Pemerintah Daerah}

Prosedur berikutnya adalah memfasilitasi pertemuan antara calon peserta program pemberdayaan pendidikan. Pertemuan antara keluarga mampu dan keluarga kurang mampu tersebut juga difasilitasi oleh tim mediasi yang dibentuk oleh Pemerintah Kota Kendari. Prosedur ini ditempuh untuk menyatukan 
persepsi antara calon keluarga yang akan diberdayakan.Tim mediasi tersebut dibentuk oleh Walikota Kendari. Tim mediasi beranggotakan selain dari unsur BPM-PK sendiri, anggota tim mediasi juga berasal dari unsur press, diantaranya TVRI Sulawesi Tenggara, Kendari Ekpres, Kendari Pos, Media Sultra, dan Pos Kita.

\section{Penandatanganan Akta Pemberdayaan Pendidikan yang Dilakukan Dihadapan Walikota Kendari yang Disaksikan Wakil Walikota dan Sekretaris Kota Kendari}

Dalam akta persaudaraan madani menerangkan bahwa mereka dipersaudarakan atas dasar niat yang ikhlas dan kesadaran sosial yang tinggi, mereka wajib membina hubungan persaudaraan, saling menjaga kehormatan, saling membantu dalam kebaikan, saling mendoakan untuk kesehatan, rejeki dan keselamatan yang dilakukan sesuai kaidah-kaidah agama, sehingga kedua keluarga dapat hidup layak, mendapat rahmat dan ridho Allah SWT.

\section{Pembahasan}

Penanggulangan kesenjangan pendidikan di Indonesia, pemerintah telah menyelenggarakan berbagai program pemberdayaan pendidikan seperti program wajib belajar 9 tahun (Undang-Undang Republik Indonesia Nomor 20 Tahun 2003 tentang Sistem Pendidikan Nasional), Program Indonesia Pintar (Permendikbud No 10 Tahun 2020). Program pemerintah tersebut bertujuan untuk meningkatkan angka partisipasi anak dalam bidang pendidikan.

Selain pemerintah, pihak swasta juga turut serta berpartisipasi menyelenggarakan pemberdayaan pendidikan, seperti di beberapa daerah di Indonesia, beberapa Lembaga pendidikan yang dikelola pihak swasta turut serta melakukan pemberdayaan pendidikan kepada masyarakat(Safri Miradj, 2014)

Namun baik pemerintah maupun pihak swasta tersebut melaksanakan pola pemberdayaan dengan menggunakan sumber pembiayaan dari negara sedangkan pihak swasta menggunakan dana dari lembaga-lembaga donor dan beberapa juga bersumber dari negara.

Berbeda dengan program pemberdayaan yang dicetus oleh pemerintah Kota Kendari, keterlibatan pemerintah hanya sebatas fasilitator dan mempertemukan warga mampu dengan warga kurang mampu. Warga mampu kemudian memberdayakan satu keluarga kurang mampu tersebut. Pola pemberdayaan ini oleh pemerintah Kota Kendari diberi nama program One Help One(Wawancara dengan Walikota Kendari)

Peran pemerintah sebagai fasilitator dalam program pemberdayaan pendidikan ini telah sesuai dengan peran pemerintah didalam peningkatan pendidikan yaitu peran sebagai pelayan masyarakat, sebagai fasilitator, sebagai pendamping (Astawa, 2017) namun peran sebagai penyandang dana pada program pemberdayaan pendidikan ini tidak dilakukan oleh pemerintah, sumber dana untuk melakukan pemberdayaan pendidikan ini murni dari warga mampu yang terlibat dalam program pemberdayaan pendidikan dengan pola One Help 
One tersebut, program inilah yang membedakan program pemberdayaan One Help One ini dengan program pemberdayaan sebelumnya.

Program pemberdayaan pendidikan dengan pola One Help One ini telah dijalankan mulai pada awal program ini berjalan pada tahun 2008, hingga tahun 2017. Program pemberdayaan pendidikan ini telah membantu warga kurang mampu sebanyak 283 kepala keluarga.

Berdasarkan wawancara dengan informan warga Kelurahan Lepo-Lepo mengatakan bahwa sebelum melakukan pemberdayaan pendidikan kepada keluarga kurang mampu yang terpilih, para peserta program pemberdayaan pendidikan tersebut terlebih dahulu dipertemukan oleh suatu tim yang dinamakan tim mediasi, dan selanjutnya setelah masing-masing pihak sepakat untuk mengikuti program pemberdayaan pendidikan, maka selanjutnya dilakukan penandatanganan akta pemberdayaan. Penandatanganan akta pemberdayaan pendidikan ini dilaksanakan antar kedua belah pihak yang disaksikan oleh Walikota Kendari, Wakil Walikota dan Sekretaris Daerah.

Selanjutnya setelah ada kesepakatan antara peserta program pemberdayaan pendidikan tersebut, maka peserta program pemberdayaan pendidikan menandatangani akta pemberdayaan, maka setiap pasangan peserta program pemberdayaan pendidikan tersebut sepakat untuk melakukan pemberdayaan pendidikan berupa (1) membantu pendidikan anak, minimal sampai pada tingkat pendidikan dasar, atau (2) diberikan kursus keterampilan bidang tertentu, atau (3) diikutkan dalam pelatihan kewirausahaan tertentu, serta (4) mendorong untuk memahami dan menjalankan ajaran agama yang dianut keluarga miskin yang bersangkutan. Pihak yang telah mengikuti program pemberdayaan pendidikan tersebut dapat memilih beberapa poin dari aspek Pendidikan. Hasil wawancara dengan informan penelitian pada umumnya mengatakan bahwa keluarga yang berdayakan mereka memberikan bantuan berupa bantuan pendidikan anak mereka sampai minimal tamat pendidikan dasar, dan ada juga yang dibantu ikut kursus menjahit. Wawancara dengan seorang informan dari Kelurahan Wawowanggu mengatakan saudara yang berdayakan mereka memberikan bantuan pendidikan kepada anaknya hingga tamat SMA dan setelahnya itu membantu untuk mengikutkan kursus dibidang elektronik

Pola pemberdayaan pendidikan yang dilaksanakan oleh keluarga mampu terhadap saudaranya yang kurang mampu dari aspek pendidikan ternyata sangat membantu pemerintah dalam mengentaskan pendidikan dasar Sembilan tahun (Undang-Undang Republik Indonesia Nomor 20 Tahun 2003 tentang Sistem Pendidikan Nasional). Banyak warga masyarakat yang berkategori mampu turut terlibat memberdayakan warga masyarakat yang kurang mampu. Tentang keterlibatan warga negara dalam pemberdayaan pendidikan juga sejalan dengan pendapat yang dikemukakan oleh Organization for Economic Cooperationand Development(Rahman, 2016) yang mengatakan bahwa adanya keterlibatan warga negara mulai dari levelyangterendah yaitu informasi,kemudiankonsultasi sampai ke leveltertinggi yaitu partisipasi aktif. 


\section{SIMPULAN}

Program pemberdayaan pendidikan merupakan salah satu program pemberdayaan Persaudaraan Madani atau One Help One. Program ini mempersaudarakan antara keluarga mampu dengan keluarga kurang mampu dengan landasan saling asah, asih dan asuh antar sesama warga kota. Pemerintah Kota Kendari dalam program pemberdayaan pendidikan ini bertindak untuk memfasilitasi peserta program dimulai tahap pengambilan data profil peserta program, melakukan sosialisasi kepada calon peserta program, dilakukan fasilitasi pertemuan oleh tim mediasi pemerintah daerah hingga dilakukannya penandatanganan akta pemberdayaan pendidikan yang dilakukan dihadapan Walikota Kendari yang disaksikan Wakil Walikota dan Sekretaris Kota Kendari. Hingga tahun 2016 telah melibatkan 283 Kepala Keluarga dalam program ini, adapun jenis kegiatan pada program pemberdayaan ini adalah (1) membantu pendidikan anak, minimal sampai pada tingkat pendidikan dasar, atau (2) diberikan kursus keterampilan bidang tertentu, atau (3) diikutkan dalam pelatihan kewirausahaan tertentu, serta (4) mendorong untuk memahami dan menjalankan ajaran agama yang dianut keluarga miskin yang bersangkutan. Program pemberdayaan ini murni dilakukan oleh warga masyarakat secara mandiri, adapun keterlibatan pemerintah hanya memfasilitasi program ini agar dapat berjalan dengan baik ditandai dengan adanya keterlibatan masyarakat.

\section{DAFTAR PUSTAKA}

\section{Jurnal Artikel:}

Agustini, Fauzia. Dkk. (2018). Desain Model Pemberdayaan Dosen Di Kota Medan. Jurnal Manajerial, Vol. 3 No.5 Juni 2018, Hal - 168 http://ejournal.upi.edu/index.php/manajerial.

Astawa, Nyoman Temon, (2017) Memahami Peran Masyarakat Dan Pemerintah Dalam Kemajuan Mutu Pendidikan Di Indonesia. Jurnal Penjaminan Mutu Lembaga Penjaminan Mutu Institut Hindu Dharma Negeri Denpasar.http://ejournal.ihdn.ac.id/index.php/JPM.

Eka, Nurcahya; Alexandri, Muhammad Benny.(2020).Analisis SWOT Penanggulangan Kemiskinan di Kota Bandung. JurnalModerat Vol.6 No.2. https://jurnal.unigal.ac.id/index.php/moderat/article/download/3354/3078

Elwan and Aslim (2019). Permasalahan Pekerja Anak di Kota Kendari. Journal of Public Administration and Government. Volume 1. Nomor 1. April 2019. Hal 27-33.

Endah, Kiki. (2020). Pemberdayaan Masyarakat : Menggali Potensi Lokal Desa. Jurnal Moderat, 135-143. https://jurnal.unigal.ac.id/index.php/moderat

Harahap, Erni Febrina. (2012) Pemberdayaan Masyarakat Dalam Bidang Ekonomi Untuk Mewujudkan Ekonomi Nasional yang Tangguh dan Mandiri. Jurnal Manajemen dan Kewirausahaan. , Volume 3, Nomor 2, Mei 2012 ISSN : 2086 $-5031,78-96$.

Indarwati, Rizky (2017). Strategi Pelaksanaan Tim Pemberdayaan Kesejahteraan Keluarga (PKK) Dalam Meningkatkan Pemberdayaan Perempuandi Kecamatan Samarinda Utara. eJournal Ilmu Pemerintahan, Volume 5, 
Nomor 2, 2017: 861-872.

Kadir, Siti Fatimah. (2013). Meningkatkan Mutu Pendidikan Melalui Pemberdayaan Masyarakat. 164-175. Jurnal Al-Ta'dib. Vol. 6 No. 1 JanuariJuni.

Margayaningsih, D. I. (2018). Peran Masyarakat Dalam Kegiatan Pemberdayaan Masyarakat Di Desa. Jurnal Publiciana, 11(1), 72-88. Retrieved from https://www.journal.unita.ac.id/index.php/publiciana/article/view/140.

N. Nurwati (2008). Kemiskinan : Model Pengukuran, Permasalahan dan Alternatif Kebijakan. Jurnal Kependudukan Padjadjaran. Vol. 10, No. 1, Januari 2008: 1 11.

Puput Harianti; Barlian;Eka Suaib.(2020). Analisis Implementasi Kebijakan Kota Layak Anak di Kota Kendari. Jurnal Administrasi Pembangunan dan $\begin{array}{lllll}\text { Kebijakan } & \text { Publik } & \text { Vol. } & 1 & \text { Nol }\end{array}$ http://ojs.uho.ac.id/index.php/publika/article/download/13503/9417.

Rahman (2016). Pemberdayaan Warga Negara Dalam Pelayanan Publik Manajemen Pendidikan Dasar di Kota Kendari. e-JKPP Jurnal Kebijakan dan Pelayanan Publik. Vol. 2 No. 1 Juli 2016. Hal. 40-54.

Raintung, Anggreyni. Dkk. 2021. Peran Pemerintah Desa Dalam Pemberdayaan Kelompok Tani di Desa Mobuya Kecamatan Passi Timur Kabupaten Bolaang Mongondow. JURNAL GOVERNANCE Vol.1, No. 2. 1-9.

Rifa'l, Bachtiar (2013) Efektivitas pemberdayaan usaha mikro kecil dan menengah (UMKM) Krupuk ikan dalam program pengembangan Labsite Pemberdayaan Masyarakat Desa Kedung Rejo Kecaatan Jabon Kabupaten Sidoarjo. Jurnal Kebijakan dan Manajemen Publik.13 (1), 130-136.

S. Safri Miradj. (2014).Pemberdayaan Masyarakat Miskin, Melalui Proses Pendidikan Nonformal, Upaya Meningkatkan Kesejahteraan Sosial di Kabupaten Halmahera Barat. Jurnal Pendidikan dan Pemberdayaan Masyarakat. Volume 1 - Nomor 1, Maret 2014. Hal 101-112.

Sugiyono (2012) Memahami Penelitian Kualitatif. Bandung: Alfabeta.

Yulianti. Devi. (2018) IImplementasi Program Kemitraan Dalam Corporate Social

Responsibility (Csr) Melalui Pemberdayaan Masyarakat Untuk Mewujudkan Pembangunan Kesejahteraan. Jurnal Sosiologi, Vol. 20, No. 1: 1121: https://doi.org/10.23960/jurnal\%20sosiologi.v20i1.14.

Wahidin, Unang. Dkk. (2021) Pemberdayaan Pemuda Dalam Bidang Pendidikan Keagamaan Di Desa Cikarawang, Kecamatan Dramaga, Kabupaten Bogor. 64-77. Khidmatul Ummah: Jurnal Pengabdian Kepada Masyarakat. http://jurnal.staialhidayahbogor.ac.id/index.php/khidmatul/article/view/14 $\underline{76}$.

Buku:

Awang, Azam. (2010).Implementasi Pemberdayaan Pemerintahan Desa, Studi Kajian Pemberdayaan Berdasarkan Kearifan Lokal di Kabupaten Lingga Provinsi Kepulauan Riau. Jokjakarta. Pustaka Pelajar.

Hikmat, Harry. (2010). Strategi Pemberdayaan Masyarakat. Bandung. Humaniora 
Utama Press.

Madekhan, Ali. (2007). Orang Desa Anak Tiri Perubahan.Jokjakarta.Everroes Press.

Miles, Matthew B and Huberman, Michael A. (1992).Analisis Data Kualitatif: Buku Sumber Tentang Metode-Metode Baru. Terjemahan Tjetjep Rohendi Rohidi. Jakarta.UI-Press.

Sumodiningrat, Gunawan. 2000. Pemberdayaan Masyakat dan JPS. Jakarta: PT Gramedia

Usman, Sunyoto.(2004). Pembangunan dan Pemberdayaan Masyarakat. Jokjakarta Pustaka Pelajar. 